\title{
KAPITALISME PEDESAAN DI KAWASAN EKONOMI KHUSUS (KEK) TANJUNG LESUNG KABUPATEN PANDEGLANG PROPINSI BANTEN
}

\author{
Dede Sri Kartini \\ Rahman Mulyawan \\ Neneng Yani Yuningsih \\ Departemen Ilmu Pemerintahan \\ Fakultas Ilmu Sosial dan Ilmu Politik Universitas Padjadjaran \\ email: dedekartini@yahoo.com
}

\begin{abstract}
ABSTRAK
Kebijakan yang mengedepankan pertumbuhan ekonomi dengan mengabaikan berbagai kepentingan rakyat akan menumbuhkan kapitalisme di suatu kawasan. Dengan mengambil lokasi penelitian di Kawasan Ekonomi Khusus (KEK) Tanjung Lesung di Kabupaten Pandeglang, propinsi Banten, peneliti melihat kawasan pedesaan dirubah menjadi tempat investasi bagi siapapun yang memiliki uang, pemilik modal menjadi pengendali arah perkembangan satu kawasan. Inilah inti kapitalisme, pemerintah hanya bisa membuat regulasi tanpa bisa mengintervensi arah perkembangan pedesaan. Ironisnya, kapitalisme ini justru dipayungi oleh kebijakan publik. Desa Tanjung Jaya yang merupakan wilayah pedesaan berubah menjadi kawasan eksklusif dengan dibangunnya vila, resort, wisata pantai, sejak ditetapkannya wilayah ini menjadi Kawasan Ekonomi Khusus pariwisata pertama di Indonesia. Tulisan ini bertujuan untuk mendeskripsikan pengelolaan kapitalisme oleh pemerintah baik pusat maupun daerah yaitu Kabupaten Pandeglang.
\end{abstract}

Kata kunci: Pemerintah Daerah, Kebijakan, Kapitalisme Pedesaan

\begin{abstract}
The policy where propose economic growth and ignoring people's interest will growing capitalism in a place. Taking location of research in special economic area, Tanjung Lesung Pandeglang - Banten, we found the rural area has change to become the place investment whoever have much money. Capital owners has controlling an area development. These is capitalism. The government only can make regulation without how to intervention of rural development. Ironically, these capitalism indeed protected by policy. Tanjung Jaya village is a place where changing and become exclusive area with those build villa, resort, beach tourism, and etc., since it was set as first special economic area of tourism in Indonesia. This article aim to descript how capitalism managed by national and local government, it is Pandeglang Region.
\end{abstract}

Keywords: local government, the policy, rural capitalism

\section{PENDAHULUAN}

Fungsi pemerintah pada umumnya meliputi pengaturan, pembangunan dan pelayanan. Dalam menjalankan fungsi pembangunan, pemerintah di negara-negara berkembang terjebak dengan pembangunan fisik semata. 
Pertumbuhan ekonomi melalui kedatangan modal asing dipercaya sebagai obat mujarab untuk menekan angka kemiskinan yang tinggi. Dengan regulasi yang dibuat untuk memudahkan investasi domestik dan asing masuk, pembangunan hotel mewah dan sarana rekreasi yang modern dibangun di tengah-tengah masyarakat desa yang awam terhadap kapitalisme.

Dalam kondisi yang sama, Pemerintah Indonesia mengeluarkan kebijakan Kawasan Ekonomi Khusus (KEK) yang meliputi delapan kawasan. Kedelapan kawasan itu adalah Tanjung Lesung (Banten), Sei Mangkei (Sumatera Utara), Palu (Sulawesi Tengah), Bitung (Sulawesi Utara), Mandalika (NTB), Morotai (Maluku Utara), Tanjung Api-Api (Sumatera Selatan) dan Maloi Batuta Trans (Kalimantan Timur). ${ }^{l}$

Salah satu daerah yang menjadi perhatian adalah KEK Tanjung Lesung ${ }^{2}$ yang berlokasi di Banten. Tanjung Lesung merupakan wilayah pesisir yang terletak di Desa Tanjungjaya Kecamatan Panimbang Kabupaten Pandeglang dan sejak lama telah dikenal sebagai kawasan pariwisata karena memiliki pasir putih dan panorama yang indah, baik di daratan maupun bawah air. Hal tersebut dapat terlihat dari sebaran terumbu karang di kawasan ini yang

\footnotetext{
${ }^{1}$ Lihat Kajian Dampak Ekonomi Pemberntukan Kawasan Ekonomi Khusus, Kemendag, 2013.

${ }^{2}$ Kawasan ini menjadi perhatian peneliti, ketika membimbing praktikum lapangan mahasiswa Ilmu Pemerintahan FISIP UNPAD, tanggal 15-17 Desember 2015.

${ }^{3}$ Laporan DKP Kabupaten Pandeglang 2012
}

diketahui memiliki luas sekitar 85 hektar ${ }^{3}$. Diawali dengan Undangundang Nomor 39 Tahun 2009 tentang KEK, kemudian direspon dengan Peraturan Pemerintah (PP) Nomor 26 Tahun 2012 mengenai Kawasan Ekonomi Khusus Tanjung Lesung, semakin menguatkan peran kawasan ini sebagai kawasan pariwisata. Produk kebijakan inilah yang menurut peneliti, telah menyebabkan kapitalisme di Desa Tanjung Jaya. Peraturan Pemerintah ini ini kemudian direspon oleh Bapedda Kabupaten Pandeglang dengan Rencana $\mathrm{Aksi}^{4}$ Kelembagaan yang terdiri dari Pembentukan Dewan KEK, Pembentukan Skretariat Dewan KEK, Pembentukan Administrator KEK . Rencana Aksi Pelimpahan Kewenangan dan Penetapan Badan Usaha Pembangunan KEK Tanjung Lesung. Selain itu, dibentuk pula Administratur KEK dengan Peraturan Daerah Nomor 2 Tahun 2014 yang menjalankan Fungsi Pelayanan Satu Pintu ${ }^{5}$.

Dengan demikian Pemerintah Pusat maupun Daerah merespon peningkatan kesejahteraan dengan menggunakan konsep modernisasi perspektif historis. Perspektif ini mengemukakan bahwa dilihat dari perspektif historis dunia, modernitas berkaitan dengan keunggulan inovasi atau terobosan kesadaran, moral, etika, teknologi, dan tatanan sosial yang berguna bagi peningkatan

\footnotetext{
${ }^{4}$ Lihat bapedda.pandeglangkab.go.id. Diakses tanggal 8 Mei pukul 11.42.

${ }^{5}$ Lihat kek.ekon.go.id. Diakses 9 Mei pukul 12.30
} 
kesejahteraan manusia. (Tiryakian, dalam Sztompka, 2004: 152). Pandangan serupa dikemukakan oleh Chodak, modernisasi adalah contoh khusus dan penting dari kemjuan masyarakat, contoh usaha sadar yang dilakukan untuk mencapai standar kehidupan yang lebih tinggi. (Chodak, dalam Sztompka, 2004: 152). Peneliti memiliki argumen demikian karena pembangunan KEK Tanjung Lesung sampai saat ini belum menciptakan kesejahteraan masyarakat, malah kebijakan tersebut telah menciptakan dikotomi baik secara geografis, ekonomi dan budaya.

Dikotomi secara geografis terlihat dari kondisi perkampungan penduduk yang sederhana dengan mata pencaharian pertanian dan nelayan, disisi lain berdiri tempat wisata yang megah dengan akses masuk yang cukup ketat. Dikotomi secara ekonomi semakin kelihatan, ketika penduduk sebagian besar hanya menguasai sumber produksi yang terbatas, dengan pengelola swasta yang menguasai perekonomian di wilayah tersebut inilah kapitalisme yang ada di pedesaan. Secara budaya, masyarakat Desa Tanjung Jaya masih bersifat tradisional dan homogen, sedang masyarakat yang datang ke KEK Tanjung Lesung bersifat modern dan heterogen.

\section{RUMUSAN MASALAH}

Globalisme dan kapitalisme adalah dua hal yang tidak dapat dipisahkan, meskipun dalam keseharian konsep ini sering ditukarkan dan memiliki makna yang sama. Globalisasi memiliki makna yang lebih luas, baik itu kehidupan sosial, politik dan ekonomi, sedangkan kapitalisme mengarah pada dibukanya keran regulasi untuk kebebasan masuknya modal besar baik siang maupun domestik. Dalam tulisan ini hanya akan dibahas "Bagaimanakah kapitalisme pedesaan diregulasi?"

\section{PEMBAHASAN}

Melihat sejarahnya, berbicara kapitalisme seolah tak mungkin untuk mengabaikan Weber (Huntington, 1996) dan Adam Smith (Fakih, 2013). Kedua nama tersebut akan dikutip dalam menengok sejarah kapitalisme. Menurut Huntington, "ada tesis Weber yang menyatakan bahwa protestanisme mendorong usaha ekonomi, perkembangan borjuasi, kapitalisme, dan kemakmuran ekonomi, sehingga memperlancar munculnya lembaga-lembaga demokrasi”. Sedangkan Fakih menyatakan, Adam Smith merupakan pemikir pertama yang mengembangkan pentingnya 'akumulasi kapital' dalam pengembangan ekonomi. Teori Adam Smith tentang labour theory of value itu kemudian menjadi dasar kapitalisme.

Eko (2013) dengan mengutip dari Sutoro Eko dan Abdur Rozaki (2006) membuat pemetaan relasi antara negara, kapital dan warga. Dalam salah satu penjelansanya, menurutnya bila kantor perubahan/transformasi adalah pemilik modal, maka negara biasanya menjual regulasi dan lisensi serta melindungi pemilik kapital. Pemilik modal memperoleh keuntungan ekonomi dan politik yang sangat 
besar, sedangkan warga desa hanya memperoleh trickle down effect dari kapitalisasi, tetapi terpinggirkan dan terjadi ketimpangan. Hal ini seperti diungkapkan Saksono (2015) bahwa bila pemilik modal melakukan aktivitas ekonominya dan investasi kapital tersebut diregulasi, maka terjadilah kapitalisme.

Pembangunan merupakan sebuah aspek determinan yang bisa mempengaruhi dan dipengaruhi oleh kebijakan-kebijakan yang dibuat oleh pemerintah. Hal ini pula yang terlihat dan menjadi fokus dalam tulisan ini, dimana kebijakan pemerintah mengenai kawasan ekonomi khusus (KEK) pada hakikatnya merupakan kebijakan pemerintah dalam menghadapai perubahan sosial dunia yang sangat menjunjung tinggi sistem ekonomi kapitalis dan menganggapnya sebagai sistem yang paling tepat untuk membawa kesejahteraan kepada masyarakat. Namun disisi lain, kebijakan ini akan pula membawa perubahan sosial pada masyarakat tradisional yang berada di kawasan tersebut. Hal tersebut dikarenakan kondisi modern yang serta merta membawa konsepsi pembangunan jelas mempengaruhi kepribadian manusia. Pengaruh modernitas terhadap manusia tercermin dari urbanisme, industrialisme, mobilitas, dan komunikasi masa (Inkeles, 1976 dalam Sztompka, 2004: 95)

Pembangunan ekonomi yang berorientasi kepada sistem ekonomi kapitalis merupakan sesuatu hal yang tidak dapat dielakkan. Teori dan konsep yang menjadi kritik terhadap fenomena itu banyak dikemukakan oleh para ahli sosial, utamanya berkaitan dengan ketidakmampuan sistem ekonomi kapitalis untuk menyediakan ruang bagi terciptanya kesejahteraan yang merata. Nyatanya, sistem ekonomi ini hanya mampu memberikan kesempatan kepada para pemilik modal untuk menambah pundi-pundi kekayaannya. Sementara bagi masyarakat luas, terutama masyarakat yang masih mempercayai nilai dan sistem tradisional, sistem ekonomi ini hanya dapat memperburuk keadaan ekonomi mereka. Terlebih, masyarakat ini tidak memiliki kemampuan untuk bersaing dalam pasar bebas yang terbentuk oleh sistem ekonomi kapitalis. Yang lebih memperburuk situasi ini adalah, kebijakankebijakan yang dibuat oleh pemerintah, didasarkan kepada situasi dimana mereka sudah terlanjur mempercayai bahwa untuk mencapai kesejahteraan masyarakat, maka pembangunan ekonomi yang mengarah kepada modernisasi dan kapital inilah yang harus diterapkan. Sehingga seolah-olah kebijakan pemerintah ini hanya melindungi kepentingan-kepentingan para pemilik modal. Padahal bisa jadi, apa yang diharapkan oleh pemerintah ini adalah dengan adanya modal dan investasi ini, dapat memberikan stimulus bagi perkembangan dan pembangunan ekonomi masyarakat sekitar. Kesalahan pemerintah terletak pada, mereka tidak mempersiapkan masyarakat untuk menjadi bagian besar dari pembangunan ekonomi tersebut. Sehingga membuat masyarakat yang ada didalam ruang-ruang yang terbentuk oleh sistem ekonomi kapitalis ini hanya menjadi penonton belaka. 
Penulis melihat, bahwa pemerintah merupakan inisiator (pembuat kebijakan) dan sekaligus terlibat dalam implementasi kebijakan. Hal ini terlihat dari produk kebijakan yang dikeluarakan. Kebijakan di level nasional menggunakan Undang-undang No. 39/2009 tentang KEK. Dari Undangundang inilah muncul Peraturan Presiden No. 33 tahun 2010 tentang Dewan Nasional dan Dewan Kawasan KEK. Struktur kelembagaan dalam pengembangan KEK ada dua tingkatan, yaitu Dewan Nasinal di Pusat dan Dewan Kawasan di setiap Provinsi yang daerahnya memiliki KEK. Pada setiap KEK dibentuk Administrator. Sedangkan kegiatan usaha di KEK dilakukan oleh Badan Usaha. Administaror di Kabupaten Pandeglang dibentuk dengan Peraturan Daerah Nomor 2 Tahun 2014 yang menjalankan Fungsi Pelayanan Satu Pintu.

Undang-undang No. 39 Tahun 2009 tentang Kawasan Ekonomi Khusus memberikan indikasi adanya kapitalisme dalam peraturan tersebut. Unsur kapitalisme sudah mulai dari adanya persyaratan pembentukan Kawasan Ekonomi Khusus yang mensyaratkan salah satunya "peta lokasi pengembangan serta luas area yang diusulkan, terpisah dari pemukiman penduduk". Pasal 6 ayat 2 tersebut, secara eksplisit membuat dikotomi antara KEK dan penduduk, dan membawa berbagai konsekuensi baik bagi KEK maupun penduduk Desa Tanjung Jaya sebagai lokasi KEK tersebut berada. Selain itu, kebijakan KEK yang produknya Undang-undang ini juga menunjukkan arogansi Pemerintah Pusat terhadap Daerah. Pasal 8 menyatakan Pemerintah dapat menentukan suatu kawasan menjadi KEK tanpa mengikuti persyaratanpersyaratan sebagaimana mestinya sebagaimana yang diatur dalam Undang-undang ini. Peraturan yang dapat diabaikan oleh Pemerintah tersebut adalah:

a. peta lokasi pengembangan serta luas area yang diusulkan yang terpisah dari permukiman penduduk;

b. rencana tata ruang KEK yang diusulkan dilengkapi dengan peraturan zonasi;

c. rencana dan sumber pembiayaan;

d. analisis mengenai dampak lingkungan yang sesuai dengan ketentuan peraturan perundang-undangan;

e. hasil studi kelayakan ekonomi dan finansial; dan jangka waktu suatu KEK dan rencana strategis.

Pengelolaan KEK di Kabupaten Pandeglang yang diberikan kepada Administratur, telah memberikan kewenangan yang sangat luas kepada Lembaga Teknis Daerah ini. Lembaga yang ada di daerah ini mempunyai kewenangan yang luar biasa, yaitu :

1) Administrator KEK bertugas:

a. melaksanakan pemberian izin usaha dan izin lain yang diperlukan bagi Pelaku Usaha yang mendirikan, menjalankan, dan mengembangkan usaha di KEK;

b. melakukan pengawasan dan pengendalian operasionalisasi KEK; dan 
c. menyampaikan laporan operasionalisasi KEK secara berkala dan insidental kepada Dewan Kawasan.

2) Pelaksanaan pemberian izin sebagaimana dimaksud pada ayat (1) huruf a dilakukan melalui pelayanan terpadu satu pintu. Sedangkan pasal 24 menyatakan Administrator KEK:

a. memperoleh pendelegasian atau pelimpahan wewenang di bidang perizinan dari Pemerintah dan pemerintah daerah; dan

b. dapat meminta penjelasan kepada Badan Usaha dan/atau Pelaku Usaha di KEK mengenai kegiatan usahanya.

Kedua pasal tersebut memberikan kewenangan yang sangat luas, yaitu dari mulai memberikan ijin melalui pelimpahan kewenangan baik dari Pemerintah Pusat maupun Daerah, sampai pengawasan dan pengendalian operasional KEK melalui pelayanan satu pintu. Kewenangan seperti ini tidak ada pada Dinas atau SKPD di seluruh pemerintahan di Indonesia, sehingga kedudukan Administrator ini sangat eksklusif.

Undang-undang tersebut sejalan dengan Peraturan Daerah Nomor 2 Tahun 2014 yang juga menyatakan, Adminstrator KEK memiliki tugas sebagai perumus dan pelaksana kebijakan yang detailnya adalah :

a. Perumusan kebijakan teknis sesuai dengan lingkup tugasnya;

b. Penyelenggaraan urusan pemerintahan dan pelayanan umum sesuai dengan lingkup tugasnya; c. Pembinaan dan pelaksanaan tugas sesuai lingkup tugasnya; dan

d. Pelaksanaan tugas lain yang diberikan oleh Bupati sesuai dengan tugas dan fungsinya.

Didasarkan pada hal itu, penulis kemudian mencoba untuk melihat alternatif yang dapat menjadi katalis diantara ketiganya yakni, pemerintah, swasta pemilik kapital, dan masyarakat yang ingin mencapai kesejahteraan. Untuk itu, dari sekian konsep dan teori yang mengkritisi konsep pembangunan ekonomi yang mengarah pada sistem kapitalis ini, penulis meminjam konsepsi dari Kanishka Jayasuria untuk menjadi pisau analisis.

Menurut Jayasuria (2006 : 3435), sistem ekonomi kapitalis yang menjunjung tinggi nilai-nilai liberalisme, memiliki satu ciri khas yang sama dengan bentuk kontemporer, yakni dalam memandang sebuah pemerintahan yang berorientasi pada kesejahteraan. Keduanya berusaha untuk menciptakan subjek-subjek liberal yang tertanam di bidang produktif ekonomi. Selain itu, kedua untai liberalisme tersebut memahami hakhak properti sebagai proses inheren yang terbentuk antara sosial dan yuridis, bukan sebagai akibat spontan yang muncul dari kekuatan pasar. Pasar telah dirubah pemahamannya menjadi milik umum, tetapi dengan cara yang berbeda dari logika sosial demokratis konstitusionalisme sosial.

Jaysuria dalam tulisannya yang berjudul Statecraft, welfare, and politics of inclusion berargumentasi, bahwa kapabilitas atau kemampuan seseorang dapat menjadi penengah dan menjadi kunci rekonsiliasi antara 
konsepsi liberal tentang otonomi individu dengan komitmen sosial untuk kesetaraan. Kemampuan dan kapabilitas pemerintah dalam melibatkan semua stakeholder yang ada menjadi kunci dalam mempertemukan antara kepentingan kapital dengan kesejahteraan masyarakat secara luas.

Intinya, Kanishka Jayasuria ini ingin memunculkan "the third way" atau cara ketiga sebagai alternatif pemikiran untuk menyelaraskan antara sistem pasar (liberalisme) dengan sosialisme yang tentunya mengedepankan kesejahteraan bersama. Tentunya, alternatif ini menurut penulis dapat dilaksanakan apabila terdapat "statecraft" atau kemampuan kenegarawanan dari para aktor yang menjalankan tata pemerintahan, sehingga dapat tetap melaksanakan sebuah sistem pasar namun tetap pada prinsip untuk mencapai kesejahteraaan masyarakat secara luas. Tugas dari para aktor yang memiliki statecraft ini adalah bagaimana mereka dalam proses pembuatan regulasi untuk membuat dan mengerti secara teori sebuah kebijakan sosial yang berorientasi pada kesejahteraan namun dalam konteks pasar neo-liberalisme. Secara yuridis formal, Undang-undang tentang KEK sudah mengedepankan kesejahteraan bersama. Meskipun KEK merupakan kawasan yang padat modal, tapi di dalam KEK harus terdapat lokasi untuk usaha mikro, kecil, menengah (UMKM), dan koperasi. Namun kenyataanya, sudah dua tahun KEK berjalan di Desa Tanjung Jaya, fasilitas tersebut belum ada. Peran pemerintah yang hanya berada dalam arena regulasi, membuat pengelola KEK mengatur mekanisme harga di kawasan tersebut. Hal ini mirip dengan apa yang digagas Adam Smith, bahwa intervensi pemerintah merupakan hal yang alami dalam kehidupan ekonomi (Nayak, 1996).

Penulis sepakat dengan Lowi yang dikutip oleh Agustino (2016:21) ..liberal policies are those in which the government is used extensively to bring about social change, usually in the direction of ensuring greater level of Social equality. Memang betul, kebijakan liberal telah membawa perubahan mendasar bagi masyarakat, tapi perubahan tersebut tidak dievaluasi, kelompok manakah yang dapat dan tidak mengikuti perubahan. Liberalisme dan globalisme yang biasanya bergandengan dengan kapitalisme tidak diantisipasi, sehingga perubahan hanyalah mensejahterakan pemilik modal.

Untuk mewujudkan gagasan di atas, pemerintah daerah dituntut untuk membuat kebijakan yang berorientasi kesejahteraan rakyat dalam lingkungan yang kapitalis. Sampai saat ini, Pemerintah Daerah Kabupaten Pandeglang belum membuat regulasi turunan untuk mewujudkannya. Diperlukan sebuah kebijakan yang ideal, agar masyarakat yang tradisional dapat berdampingan dengan kelompok yang memiliki modal. Pemerintah perlu mengawasi kebijakan. Pertanyannya adalah apakah Undang-undang No. 39 tahun 2009 tentang KEK sudah ideal?. Pertanyaan ini akan dijawab dengan menggunakan teori yang dikutip oleh Nugroho.

$$
\text { Nugroho (2004) yang }
$$

mengutip dari Agustin (2001), 
Boardman (1996) dan Molan (2001) mendeskripsikan kebijakan publik yang ideal. Menurut Ian Patrick Agustin (2001) kebijakan yang ideal disebutnya sebagai pragmatisme dalam kebijakan publik, artinya model kebijakan yang menggunakan rasio "untung-rugi" dari sebuah kebijakan, seperti yang dikenalkan dalam paradigma Coast benefit analysis yang dikemukakan Boardman (1996). Setiap kebijakan memang harus memperhitungkan untung rugi tanpa mengabaikan unsur etis. Menurut Molan (2001) Pragmatisme tidak identik dengan oportunisme. Pragmatisme juga tidak sekedar praktisisme. Pragmatisme lebih mengacu kepada keharusan dari setiap ide untuk merujuk kepada konsekuensi implementasinya. Pragmatisme lebih dekat dengan gol setting theory, yakni bahwa setiap tindakan harus mengacu kepada suatu tujuan. Pragmatisme harus bersifat etis dan strategis. Bersifat etis artinya sifat pragmatis ditujukan untuk kepentingan publik dan bukan elit. (Nugroho, 2004 : 263-264). Menurut Nugroho, kebijakan yang ideal memiliki ciri-ciri sebagai berikut:

Tabel 2.1

Ciri-ciri kebijakan ideal dan menyimpang

\begin{tabular}{|c|c|}
\hline leal & \\
\hline Menja & s \\
\hline Nсра & \\
\hline Pajak & $\begin{array}{l}\text { Pajak daerah yang menghisap } \\
\text { kemampuan rakyat }\end{array}$ \\
\hline usaha & $\begin{array}{l}\text { Menjual badan-badan usaha } \\
\text { secara obral }\end{array}$ \\
\hline ngacu pada & Penyeragaman pendidikan \\
\hline kecakapan & las \\
\hline 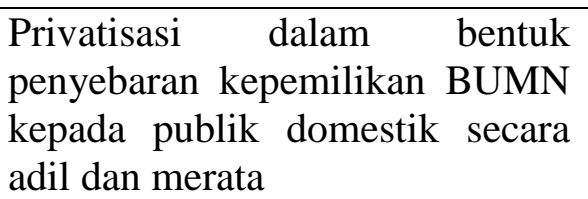 & $\begin{array}{l}\text { Privatisasi BUMN dalam bentuk } \\
\text { pemindahan monopoli dari } \\
\text { negara ke swasta, atau ke asing }\end{array}$ \\
\hline $\begin{array}{l}\text { proporsional/ sesuai } \\
\text { get } \quad \text { subsidi yang }\end{array}$ & $\begin{array}{l}\text { Subsidi tanpa batas-batas atau } \\
\text { penghapusan subsidi secara } \\
\text { total/ekstrem }\end{array}$ \\
\hline $\begin{array}{l}\text { Kesempatan yang sama bagi } \\
\text { investor domestik dan global } \\
\text { untuk menguasai aset ekonomi } \\
\text { produktif nasional }\end{array}$ & $\begin{array}{l}\text { Memprioritaskan investor global } \\
\text { untuk menguasai aset ekonomi } \\
\text { produktif nasional }\end{array}$ \\
\hline $\begin{array}{lcr}\text { Kebijakan yang } & \text { menjamin } \\
\text { penerapan } & \text { prinsip } & \text { good } \\
\text { governance } & \text { di setiap organisasi }\end{array}$ & $\begin{array}{l}\text { Kebijakan yang m } \\
\text { diskresi kepada kelor } \\
\text { menerapkan good go }\end{array}$ \\
\hline
\end{tabular}

Sumber : Nugroho, $2004: 274$ 
Melalui Undang-undang No. 39 Tahun 2009 tersebut, pemerintah memberi kemudahan bagi penanam modal di KEK dengan dipayungi oleh 9 pasal. Pasal-pasal tersebut mulai dari pasal 30 sampai dengan pasal 39, yang diantaranya sudah disebutkan di atas. Kemudahan ini juga bias hukum karena belum ada turunan regulasinya, seperti kemudahan dalam Pajak Bumi dan Bangunan, barang impor, dan Pajak Penghasilan. Undang-undang ini juga memprioritaskan investor global untuk menguasai aset ekonomi produktif nasional, contohnya pembangunan hotel yang mengambil wilayah tempat nelayan mencari ikan. Nampak disini, ada penyimpangan kebijakan bila kita menggunakan teori keijakan tersebut.

Pemerintah pada umumnya tidak dapat melepaskan diri dari globalisasi yang biasanya melekat dengan kapitalisme, tapi pemerintah dapat beradaptasi dengan berbagai konsekuensinya (Keohane: 2000). Intinya, bila mau mengadaptasi kapitalisme, harus disiapkan konsekuensi yang akan timbul. Senada dengan Keohane, Meyer yang pendapatnya dikutip oleh Riain (2000) bahwa globalisasi sebenarnya merupakan proses timbulnya masalah baru bagi negara, tapi juga memperkuat prinsip-prinsip budaya dunia bahwa negara bangsa merupakan aktor utama yang dibebani untuk mengidentifikasi dan mengelola permasalahanpermasalahn tersebut demi masyarakat.

\section{KESIMPULAN}

Kapitalisme pedesaan di KEK Tanjung Lesung deregulasi melalui produk kebijakan Undang-undang No. 39 Tahun 2009 tentang KEK. Undang-undang ini banyak memberikan kemudahan bagi pemilik modal seperti keringanan dalam Pajak Bumi dan Bangunan, Pajak Penghasilan dan Barang Impor. Secara yuridis formal, kebijakan ini seperti the third way, menjadi "jalan tengah" bagi kawasan kapitalisme tapi memberikan kesejahteraan masyarakat. Kenyataanya, hanya masyarakat yang memiliki modal saja yang dapat menikmati kebijakan ini. Kebijakan ini juga telah "merusak" tatanan sistem pemerintah daerah, karena Administratur setingkat Satuan kerja Perangkat Daerah yang ada di Kabupaten, diberi kewenangan yang luas untuk mengelola KEK Tanjung Lesung.

Di tingkat lokal, Undangundang ini kemudian direspon dengan Peraturan Daerah No. 2 Kabupaten Pandeglang tentang Pembentukan Organisasi Perangkat Daerah Kabupaten Pandeglang. Oleh Perda inipun, Adminstratur diamanti untuk melaksanakan kebijakan Dewan Kawasan, serta menyusun dan melaksakan kebijakan daerah yang berkaitan dengan KEK di tingkat Kabupaten. 


\section{DAFTAR PUSTAKA}

Agustino. Leo. 2008. Dasar-Dasar Kebijakan Publik. Alfabeta : Bandung

Eko, Sutoro, dkk. 2013. Mutiara Perubahan : Inovasi dan Emansipasi Desa Dari Indonesia Timur. ACCESS Phase II dan IRE : Yogyakarta.

Fakih, Mansour. 2013. Runtuhnya Teori Pembangunan dan Globlisasi. Pustaka Pelajar : Yogyakarta.

Huntington, Samuel P. 1996. Gelombang Demokrasi Ketiga. Penerjemah : Asril Marjohan. PT. Pustaka Utama Grafiti : Jakarta.

Jayasuriya, Kanishka. 2006. State Craft, Welfare and The Politics of Inclusion. Palgrave Mcmillan : New York

Keohane, Robert $\mathrm{O}$ and John D. Donahue. Introduction. in Joseph S. Nye and John D. Donahue (Eds). 2000. Governance In A Globalizing World. Brooking Institution Press : Washington

Nayak, Pullin B. 1996. The State and The Market. Economic and Political Weekly, Vol. 31, No. 4 (Jan. 27, 1996), pp. PE18PE22

Nugroho D, Riant. 2004. Kebijakan Publik Formulasi, Implementasi dan Evaluasi. PT. Gramedia. Jakarta

Riain, Sean O. 2000. State and Markets in an Era of Globalization. Anual Review of Sociology. Vol 6 (2000). pp 127-283
Saksono, Ign. Gatut. 2015. Bahaya Kapitalisme. Ampera Utama : Jakarta

Sztompka, Piotr. 2011. Sosiologi Perubahan Sosial. (Penerjemah : Alimandan). Prenada Media Group : Jakarta

Undang-undang No. 39/2009 tentang Kawasan Ekonomi Khusus

Peraturan Daerah Nomor 2 Tahun 2014 tentang Pembentukan Organisasi Perangkat Daerah Kabupaten Pandeglang

Kajian Dampak Ekonomi Pemberntukan Kawasan Ekonomi Khusus, Kemendag, 2013.

Laporan DKP Kabupaten Pandeglang 2012

bapedda.pandeglangkab.go.id

kek.ekon.go.id 